\title{
Muricidae (Neogastropoda) from the Middle Eocene of the Hungarian Paleogene Basin
}

\author{
Zoltán KovÁcs ${ }^{1} \&$ Zoltán ViciáN ${ }^{2}$ \\ ${ }^{1} H$-1147 Budapest, Kerékgyártó utca 27/A, Hungary.E-mail: kzkovacszoltan@gmail.com \\ ${ }^{2}$ H-1158 Budapest, Neptun utca 86, 10/42, Hungary.E-mail: kauri72@gmail.com
}

\begin{abstract}
A Middle Eocene (Lutetian-Early Bartonian) muricid assemblage with eight species is described and illustrated from the Hungarian Paleogene Basin. Three species and one genus are newly recorded in Hungary, and two new species are described: Paziella (Flexopteron) zsoldosi n. sp. and Harmatia tokodensis n. sp. With 31 figures.
\end{abstract}

Key words - Hungarian Paleogene Basin, Middle Eocene, Muricidae, new species

\section{INTRODUCTION}

The aim of this paper is to summarize the Middle Eocene Muricidae assemblage of the Hungarian Paleogene Basin system (HPB) as a contribution to the better understanding of the actual mollusc diversity of the region. Although several papers dealt with Eocene gastropods in Hungary, only two muricid species, ?Pterochelus contabulatus gantensis (Szőts) (= Murex gántensis Szőts) and Nucellopsis dudariensis (Strausz) [= Cantharus (Pollia) dudariensis Strausz, originally attributed to the Buccinidae], as well as a Murex sp. were illustrated in previous works. The Middle Lutetian-Bartonian mollusc assemblages of the HPB are similar to those of N Italy and NW France, so the lack of the Muricidae in the literature could be explained by extreme rarity and poor preservation. Middle Eocene muricids are also unknown in the adjacent regions except Ukraine (Zelinskaya et al. 1968; MAKARENKo \& Zelinskaya 1982), they were not recorded in the Bulgarian, Czech, Polish, Romanian, Slovakian, and Slovenian literature (see e.g. PAPŠOvÁ 1972; MoISESCU et al. 1991 and MikUŽ et al. 2013 with additional references). In the Priabonian muricid specimens appear sporadically in Poland (KUźNIAR 1910; KRACH 1985) and Bulgaria (KARAgIULEVA 1964), while the family is relatively diverse in the Ukrainian Archipelago (Klushnikov 1958; PaCaud 2018). 
During the last years new Eocene fossiliferous localities were exposed in $\mathrm{W}$ Hungary by fossil collectors, and occurrences of numerous previously unrecorded gastropods inclined us to revise the public collections (Hungarian Natural History Museum, Natural History Museum of the Eötvös University, Mining and Geological Survey of Hungary), as well as to search muricid specimens in the available private collections. As a result eight species are described and illustrated in this paper. Three species: Timbellus barattus (De Gregorio), T. micropterus (Deshayes), T. priabonicus Pacaud, and the typhinine genus Typhina are recorded for the first time in Hungary. In addition, two new species: Paziella (Flexopteron) zsoldosi n. sp. and Harmatia tokodensis n. sp. are designated.

The Alpine Tethys province became a deep sea during the Middle Lutetian sea transgression (Fig. 1A). The Middle-Late Eocene HPB (E Alpine Tethys) is a system of small sub-basins belonging to larger regions (HAAS 2012). The studied sites are located in the NE Bakony Mts, the Vértes Hills and the Gerecse Mts regions (Fig. 1B).

The lithostratigraphy of the Eocene formations in Hungary was summarized by Kercsmár (2015). The Middle Eocene palaeogeography and the lithological formations of the Dudar-Balinka Basin (NE Bakony Mts) were treated by BÁLDI-BEKE \& BÁLDI (1990). The diverse uppermost Lutetian shallow marine sublittoral deposits of the area with clayey sand, nummulitic sandstone, and grey marl or siltstone (Csernye Formation) have yielded very rich invertebrate assemblages. Molluscs from the brown coal mine of Dudar were described by STRAUSZ (1966, 1969, 1970a, b), Ozsvárt (2007), and Vicián et al. (2017), while from mines of Balinka by KECS KEMÉTI-KÖRMENDY (1980). The specimens illustrated in this paper from Dudar were collected on mine dumps and from a new opencast brown coal mining excavation ( $\left.47^{\circ} 17^{\prime} 55^{\prime \prime} \mathrm{N}, 17^{\circ} 55^{\prime} 31^{\prime \prime} \mathrm{E}\right)$. Eocene formations of the Tés Plateau were not treated in detail in the literature, only outcrops of the Upper Lutetian-Bartonian nummulitic Szöc Limestone was mentioned west of Tés village. A new forest road cut locality north of Tés ( $47^{\circ} 16^{\prime} 22^{\prime \prime} \mathrm{N}, 18^{\circ} 01^{\prime}$ 07” E) was discovered by Márton Zsoldos in 2016. The fossiliferous sandy clay belongs to the Csernye Formation, the solitary coral, brachiopod, and mollusc assemblages represent coastal to shallow marine palaeoenvironment.

Middle Eocene deposits of the Vértes Hills were discussed by BUDAI \& Fodor (2008). The fossiliferous beds of the Gánt Depression (S Vértes) with grey silty clay or marl and thin coaly clay intercalations of lagoon or shallow marine origin represent the Upper Lutetian Forna Formation. Mollusc assemblages from the vicinity of Gánt were presented by Szöts (1953), STrausz (1962), Mihály \& Vincze (1984), Dell'Angelo et al. (2015), and Pacaud \& Vicián (2019). Gastropods of the Nagyegyháza-Mány Basin (NE Vértes) were studied by 


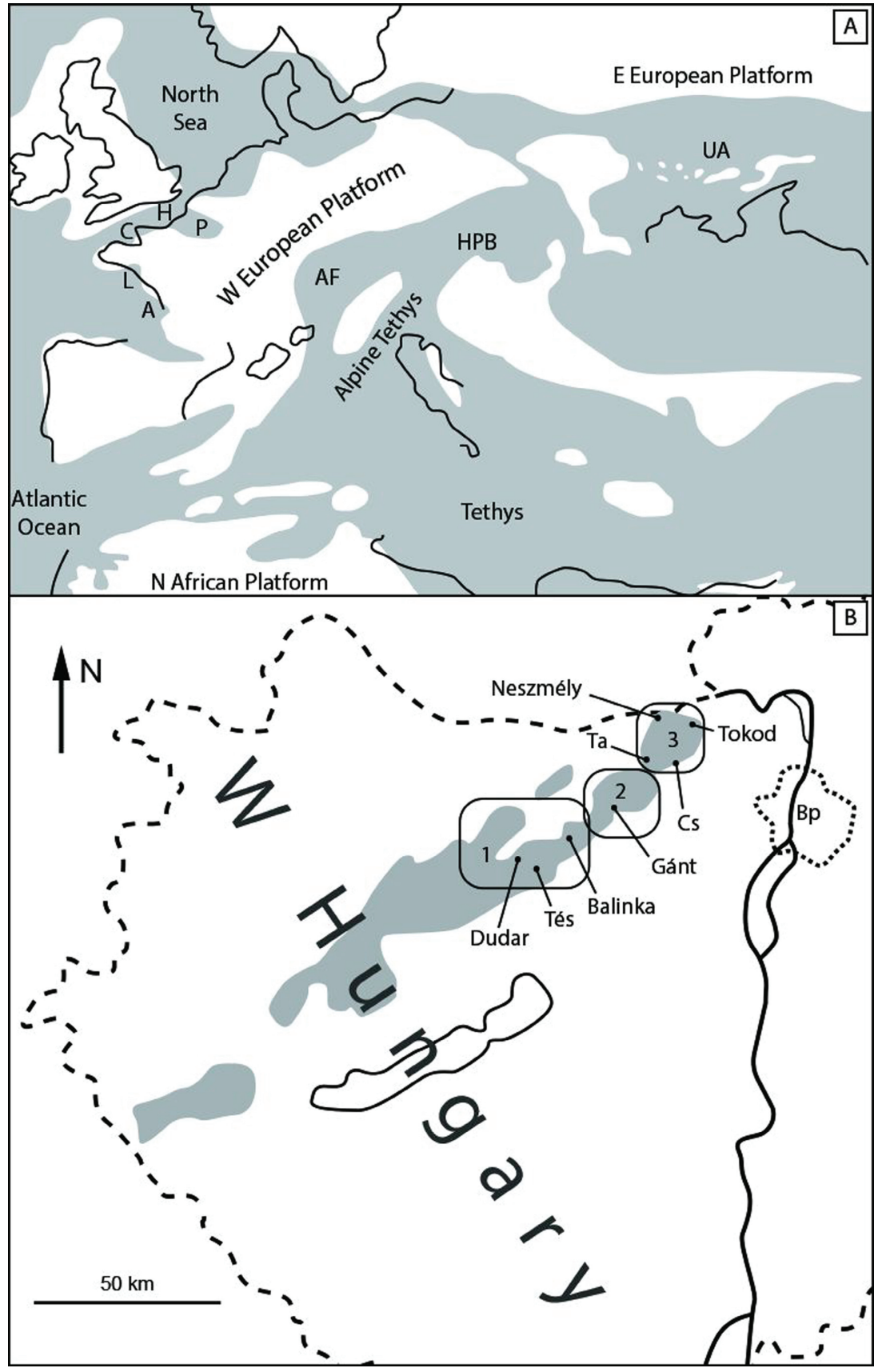

Fig. 1A. Middle Eocene palaeogeography of Europe with the location of the Hungarian Paleogene Basin (HPB) system. A = Aquitanian Basin; $\mathrm{C}=$ Cotentin Basin; $\mathrm{H}=$ Hampshire Basin; $\mathrm{L}=$ Loire Basin; P = Paris Basin; AF = Alpine Foredeep; UA = Ukrainian Archipelago (modified from BITNER et al.2011). 1B. Lutetian-Lower Bartonian deposits in the HPB, and the locations of the sites mentioned in the text. 1 = NE Bakony Mts; 2 = Vértes Hills; $3=$ Gerecse Mts; Bp = Budapest; Cs $=$ Csabdi; $\mathrm{Ta}=$ Tatabánya $($ modified from HAAs 2012$)$ 
KECS KEMÉTI-KÖRMENDY (1990) from boreholes, and by OzsvÁRT (1999) from the Csordakút opencast mine.

The Middle Eocene litho- and biostratigraphy of the Gerecse Mts were summarized by BUDAI (2018). All specimens studied herein derived from the deep neritic deposits of the Upper Lutetian-Lower Bartonian Csolnok Formation composed of grey clay, clay marl, and silt. The base of the Bartonian Stage in this formation cannot be delimited precisely as it is located within the NN16 Nannoplankton Zone. The Tekeres Creek locality close to Neszmély village (N Gerecse) was studied by STRAUSZ (1974). The mollusc assemblage contains a rich gastropod fauna characterized by the dominance of small-size species. The geology of the Dorog Basin was treated by Less et al. (2000), mollusc faunas from boreholes and quarries in the vicinity of Tokod were described by KecsKeméti-Körmendy (1972). Gastropods in the Tatabánya Basin are known only in fauna lists (SzöTs 1956).

\section{MATERIALS AND METHODS}

The studied materials are stored in the Hungarian Natural History Museum (HNHM), the Mining and Geological Survey of Hungary (MGSH), the International Fossil Shell Museum (IFSM) (the Netherlands), as well as in private collections of Tibor Berta (Veszprém), Zoltán Evanics (Mindszent), István Gurdon (Veszprém), Zoltán Vicián (Budapest), and Márton Zsoldos (Bakonynána), Hungary.

The Muricidae taxonomy and terminology follow MERLE (2001, 2005a) and MerLe et al. (2011). Abbreviations: SL - shell length (given in $\mathrm{mm}$ ), $\mathrm{P}$ - primary spiral cord, D - apertural denticle.

\section{SYSTEMATIC PALAEONTOLOGY}

Clade Neogastropoda Wenz, 1938

Superfamily Muricoidea Rafinesque, 1815

Family Muricidae Rafinesque, 1815

Genus Timbellus De Gregorio, 1885

Type species: Murex latifolius Bellardi, 1872

Timbellus barattus (De Gregorio, 1895)

(Fig. 2)

1895 Murex barattus De Gregorio - De Gregorio, p. 10, pl. 1, fig. 14.

2011 Timbellus barattus (De Gregorio) - MERLE et al., p. 444, pl. 100, figs 1-2.

Material - Coll. Gurdon (1 specimen). 
Remarks - The specimen figured here is very close in morphology to the $T$. barattus material presented by MERLE et al. (2011, pl. 100, fig. 1). The species differs from other Middle Eocene Timbellus by rounded wide ovate aperture and straight siphonal canal. The presence in the Upper Lutetian deposits of Dudar extends both the geographic and the stratigraphic ranges of $T$. barattus. The species is a new record in the HPB.

Distribution - Lutetian, Hungarian Paleogene Basin: Dudar. Priabonian, NE Atlantic: Aquitanian Basin (France). Rupelian, Alpine Tethys: Bassano (N Italy).

Timbellus micropterus (Deshayes, 1835)

(Figs 3-7)

1835 Murex micropterus - DeshaYes, p. 596, pl. 82, figs 3-4.

1880 Murex (Pteronotus) parvulmicropterus De Gregorio - De Gregorio, p. 96, pl. 7, fig. 54.

1910-1913 Murex (Pteropurpura) micropterus (Deshayes) - Cossmann \& Pissarro, pl. 35, fig. $169 / 3$.

2011 Timbellus micropterus (Deshayes) - MERLE et al., p. 448, pl. 102, figs 1-5.

Material - HNHM INV 2020.22. (1), Coll. Gurdon (1), Coll. Vicián (1), Coll. Zsoldos (1).

Remarks - The specimens are rather worn or fragmentary but the shell proportions and traces of spiral cords agree with the T. micropterus material illustrated by MerLe et al. (2011, pl. 102, figs 1-5). The type of Murex parvulmicropterus De Gregorio is a fragmentary juvenile specimen. It corresponds in size and morphology to T. micropterus but slightly differs in sculpture with weakly developed intervarical nodes. $M$. parvulmicropterus was proposed as a junior synonym of T. micropterus by MERLE et al. (2011), this arrangement is accepted herein. The small Late Eocene-Early Oligocene Timbellus rigidus (Oppenheim, 1901) (recorded from N Italy, S Czechia and S Poland) is a similar species but distinguishable by stratigraphic range and axial sculpture of marked, narrow intervarical ribs (see Oppenheim 1901, pl. 1, fig. 1; Oppenheim 1922, pl. 5, fig. 6; Krach 1985, pl. 9, figs 8-10). T. micropterus is a new record in the HPB.

Distribution - Lutetian-Bartonian, NE Atlantic: Paris, Cotentin, and Loire Basin (France), Hampshire Basin (England), Alpine Tethys: San Giovanni Ilarione (N Italy), Hungarian Paleogene Basin: Dudar, Gánt, Tés.

Timbellus priabonicus Pacaud, 2018

(Figs 8-10)

1889 Murex trialatus - Koenen, p. 45, pl. 2, figs 1-3 (non Murex trialatus G. B. Sowerby, 1834) 1968 Typhis schlotheimi - Zelins KaYA et al., pl. 14, figs 13-14.

2018 Timbellus priabonicus nom. nov. for Murex trialatus Koenen, 1889 - PACAud, p. 111, fig. $4 / \mathrm{E}-\mathrm{G}$. 
Material - HNHM INV 2020.23.1-2. (2), Coll. Vicián (3).

Remarks - The morphology of the studied specimens (trivaricate shell, paucispiral protoconch, six rounded teleoconch whorls, long and straight siphonal canal, moderately developed spiral cords: $10-11$ on the last whorl, wing-like varices, one fine intervarical rib between the varices) correspond to that of $T$. priabonicus. Other Timbellus species also appear in the Middle Eocene Alpine Tethys. From N Italy T. tripteroides (Lamarck, 1822) (= Murex stoppani De Gregorio, 1880) is known, while T. crenulatus tricarinatus (Lamarck, 1803) was recorded by DAINELLI (1915) and FABI ANI (1915). T. crenulatus tricarinatus otherwise shows a wide geographic distribution: NE Atlantic (France, MERLE et al.

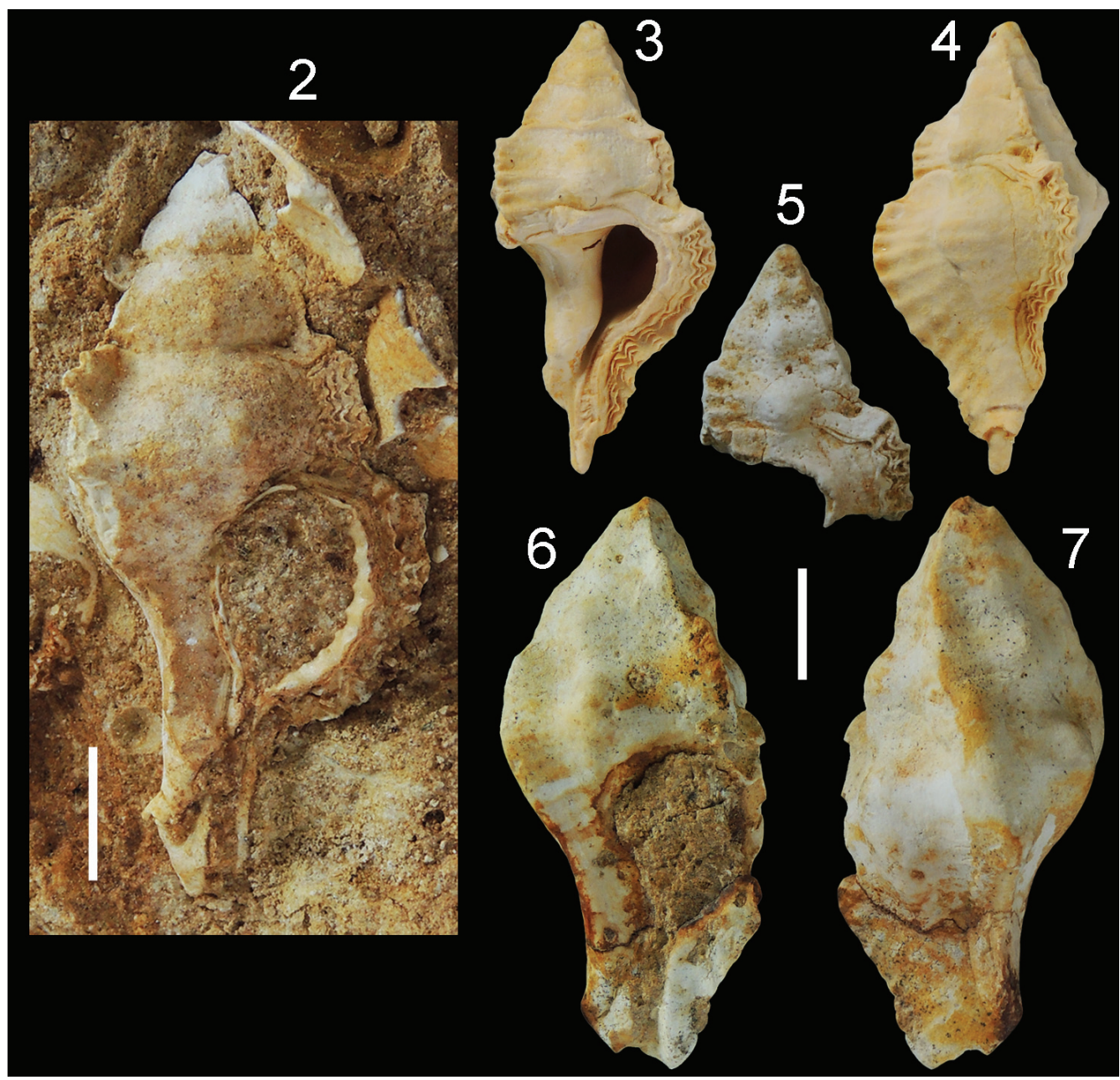

Fig 2. Timbellus barattus (De Gregorio), Coll. Gurdon, Dudar, SL 28, apertural view. - Figs 3-7. Timbellus micropterus (Deshayes). - Figs 3-4. Coll. Vicián, Gánt, SL 22. - Fig. 3. Apertural view. - Fig. 4. Abapertural view. - Fig. 5. HNHM INV 2020.22., Tés, SL 13, lateral view. - Figs 6-7. Coll. Gurdon, Dudar, SL 26. - Fig. 6. Apertural view. - Fig. 7. Abapertural view. Scale bar: 5 mm 

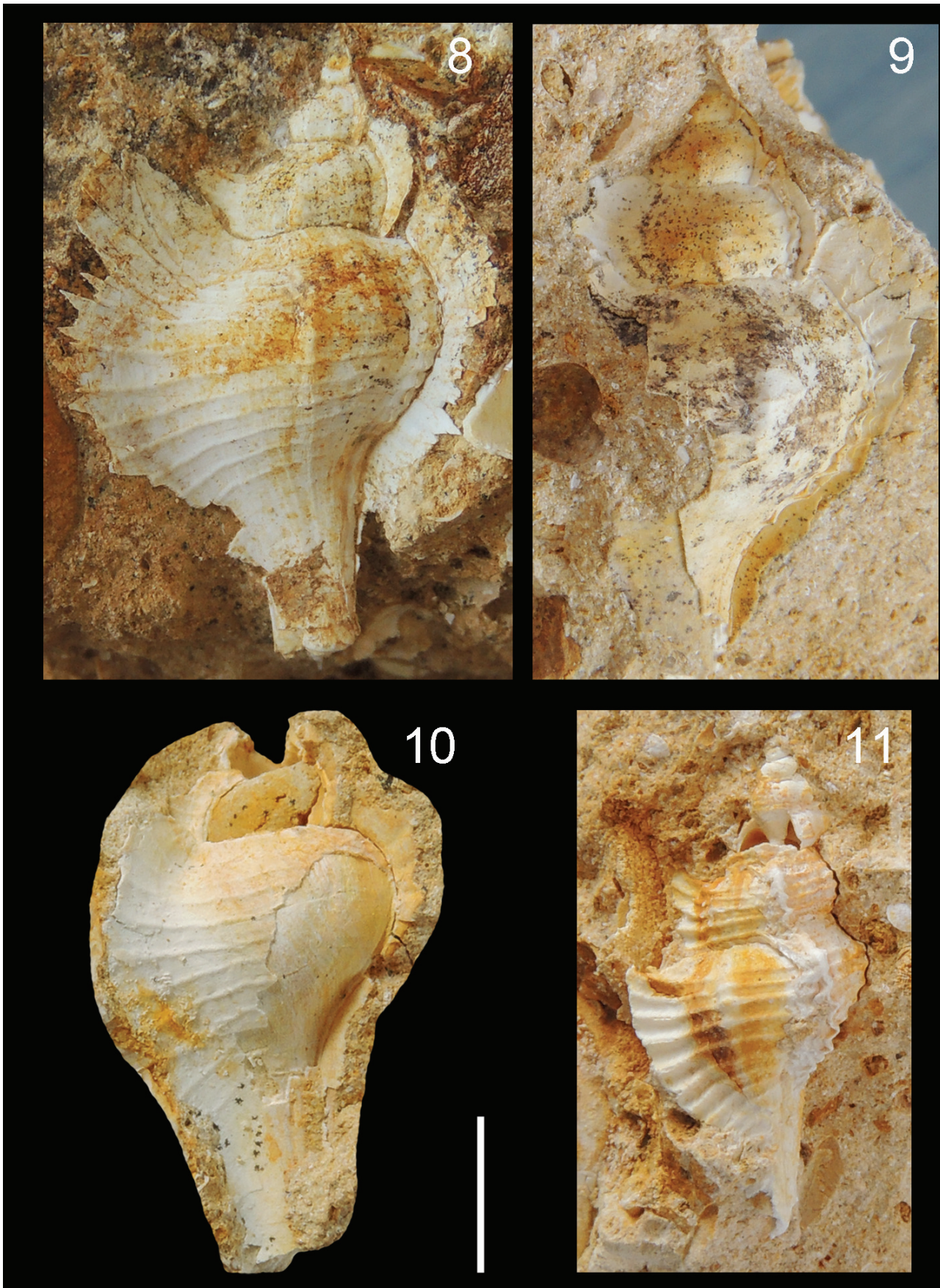

Figs 8-10. Timbellus priabonicus Pacaud. - Fig. 8. Coll. Vicián, Dudar, SL 19, abapertural view. Fig. 9. Coll. Vicián, Dudar, SL 20, abapertural view. - Fig. 10. HNHM INV 2020.23.1., Dudar, SL 18, abapertural view. - Fig. 11. ?Pterochelus contabulatus gantensis (Szőts), Coll. Vicián, Dudar, SL 16 , abapertural view. Scale bar: $5 \mathrm{~mm}$ 
2011; England, Tracey et al. 1996), North Sea Basin (Belgium, Glibert 1933), NE Alpine Tethys (Tatra Mts, Poland, KuŹniar 1910), Ukrainian Archipelago (MAKARENKO \& ZELINSKAYA 1982). The specimen illustrated by ZELINSKAYA et al. (1968, pl. 15, figs 13-14) as Typhis schlotheimi from the Late Eocene of Ukraine is identical in morphology with the Murex trialatus specimen figured by Koenen (1889, pl. 2, fig. 3), therefore it represents Timbellus priabonicus. The presence of T. priabonicus in the Late Lutetian HPB extends both the stratigraphic and the geographic ranges of the species.

Distribution - Lutetian, Alpine Tethys: Hungarian Paleogene Basin: Dudar. Priabonian, North Sea Basin (Germany), Ukrainian Archipelago.

Genus Pterochelus Jousseaume, 1880

Type species: Murex acanthopterus Lamarck, 1816

?Pterochelus contabulatus gantensis (Szöts, 1953)

(Figs 11-16)

v 1953 Murex gántensis (sic.) nov. sp. - Szöts, p. 181, pl. 6, figs 3-5.

v 1974 Murex (Pterynotus) contabulatus gantensis Szőts - STRAUSz, p. 118, pl. 3, figs 1-2.

2020 Pterochelus contabulatus - DULAI, p. 200, fig. E.

Material - MGSH: E.125 (holotype), E.126 (2), E.5194 (1), E.5207 (1), E.5270 (7), E.5285 (6), E.5514 (2), E.5905 (1); HNHM: M.59.7443 (>70), M.59.7444 (10), M.61.2423 (2), INV 2020.24. (1); Coll. Berta (4), Coll. Evanics (1), Coll. Zsoldos (2), Coll. Vicián (1).

Remarks - The "exceptional" similarity between Murex contabulatus Lamarck, 1803 and M. gantensis nov. sp. was already noted by SzöTs (1953). Later STRAUSZ (1974) revised gantensis, and emended it as a subspecies of ?P. contabulatus. Based on morphological differences (the teleoconch whorls of gantensis are more constricted at the base and the spines are slightly more curved than that of contabulatus, see MerLe et al. 2011, pl. 115, figs 5-9) the arrangement suggested by Strausz is accepted herein, and ?P. contabulatus gantensis is regarded as a geographic subspecies. "Murex" contabulatiformis Schauroth, 1865 from the Italian Eocene is a similar form but differs by more angulate whorls. ?P. contabulatus gantensis is widespread and relatively abundant in the HPB.

Distribution - Lutetian-Bartonian, Hungarian Paleogene Basin: Dudar, Gánt, Csákvár, Tés, Balinka, Mesterberek, Neszmély, Tatabánya/Felsőgalla.

Genus Paziella Jousseaume, 1880

Subgenus Flexopteron Shuto, 1969

Type species: Flexopteron philippinensis Shuto, 1969 


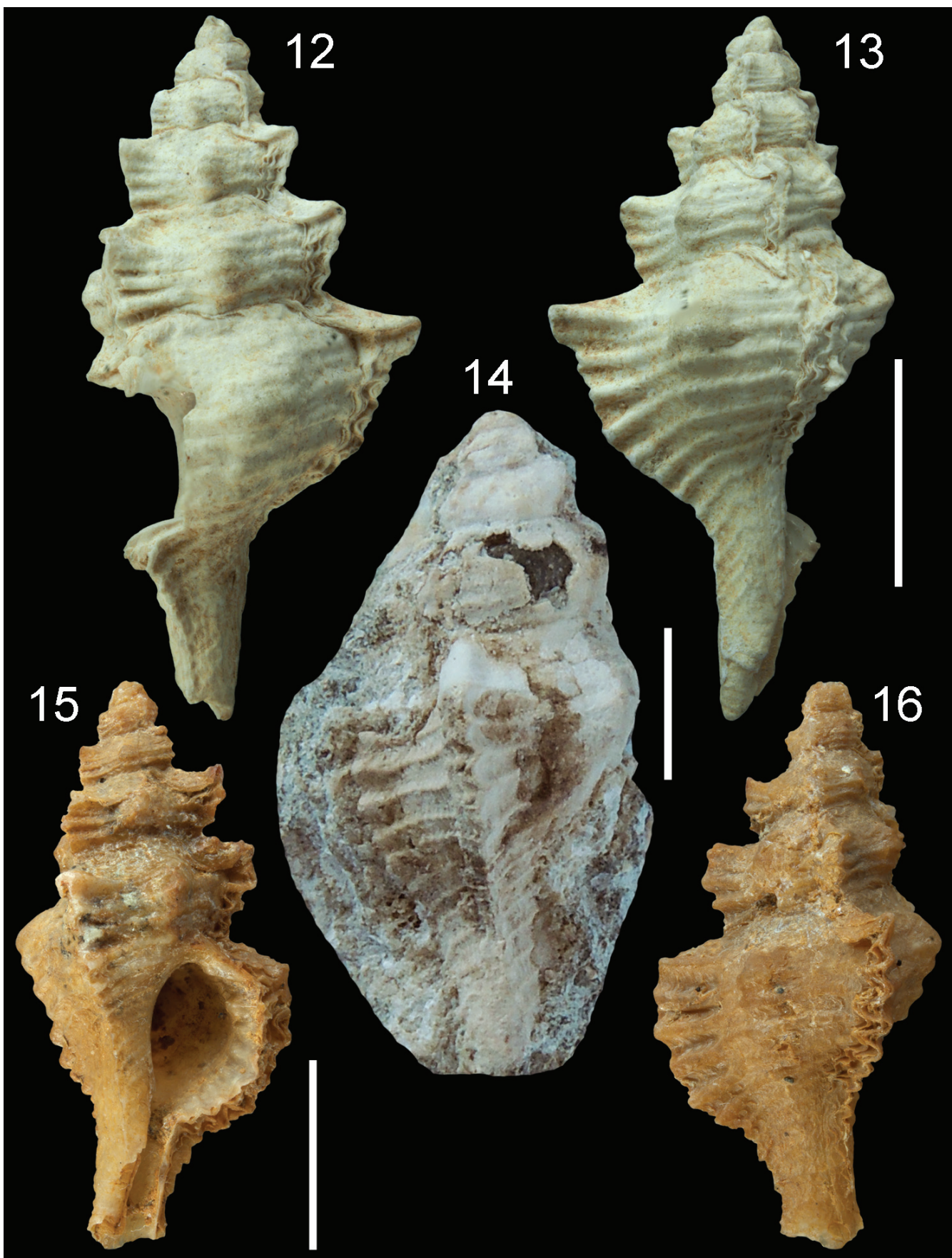

Figs 12-16. ?Pterochelus contabulatus gantensis (Szőts). - Figs 12-13. MGSH E.125, holotype of Murex gantensis Szőts, Gánt, SL 15.4, lateral views. - Fig. 14. Coll. Zsoldos, Balinka, SL 22, lateral view. - Figs 15-16. HNHM M.61.2423., Tatabánya/Felsőgalla, SL 15. - Fig. 15. Apertural view. -

Fig. 16. Abapertural view. Scale bar: $5 \mathrm{~mm}$ 


\section{Paziella (Flexopteron) zsoldosi n. sp.}

(Figs 17-21)

1990 Murex sp. - KeCS KEMÉTI-KöRMENDY, p. 164, pl. 29, figs 5-6.

Holotype - HNHM PAL 2020.20.1., SL 13 (Figs 19-20).

Type strata and locality - Upper Lutetian sandy clay, Tés, Hungary.

Derivation of name - In honour of the collector: Márton Zsoldos (Bakonynána, Hungary).

Material - Holotype and two additional specimens (Figs 17-18, 21).

Diagnosis - Paziella (Flexopteron) species with multispiral protoconch and five teleoconch whorls, ovate aperture with strong denticles within, smooth columella, sculpture of strong spiral cords and numerous axial varices.

Description - Multispiral protoconch of $31 / 4$ smooth, rounded whorls, five shouldered teleoconch whorls, elongated spire, broad subsutural slope, ovate aperture, outer lip thickened by growth lamellae, strong denticles within (D1-D5; D1-D3 stronger than D4-D5), weakly developed parietal callus, smooth columella, elongated and slightly curved siphonal canal, spiral sculpture of strong primary cords (P1-P6 on the last whorl), axial sculpture of numerous sharp varices (eight on the last whorl).

Remarks - Based on morphology the new species is assigned to subgenus Paziella (Flexopteron). The fragmentary Murex sp. from the shallow marine deposits of borehole Cs.115 at Csabdi (KeCsKeméti-Körmendy 1990, pl. 29, figs 5-6; refigured on Figs 17-18) is considered herein as a representative of $P$. $(F$.) $z$ soldosi n. sp. (unfortunately this specimen is not available in the mollusc collection of the MGSH). According to KeCSKEMÉTi-KöRMENDY (l. c.) the smooth, multispiral protoconch, the rounded early teleoconch whorls, as well as the weakly developed primary spiral cords and the sharp axial varices are closely allied to that of $P$. (F.) flexuosa (Deshayes). However, these features are common on different Eocene species of the subgenus, consequently the species level determination depends on the adult morphology. The adult shell of $P$. (F.) zsoldosi $\mathrm{n} . \mathrm{sp}$. is distinguishable from the Early Eocene $P$. $(F$.) flexuosa (Deshayes, 1865) and $P$. (F.) ogormani (Cossmann, 1923) by much stronger spiral cords and lack of spines; from the Middle Eocene $P$. (F.) foliacea fraterculus (Deshayes, 1865) by elongated spire, more widely spaced varices and lack of spines, and from the Middle Eocene $P$. (F.) elatior (Koenen, 1889) by less elongated shell and different sculpture (see Merle et al. 2011, pls 135-138). The teleoconch whorls of Paziella (Flexopteron) sp. specimens from Tés (Figs 20-22) are broader, they represent another species.

The material came from the sandy clay deposits of the Tés locality. It was associated by coastal to shallow water gastropods: Pseudobellardia auriculata 


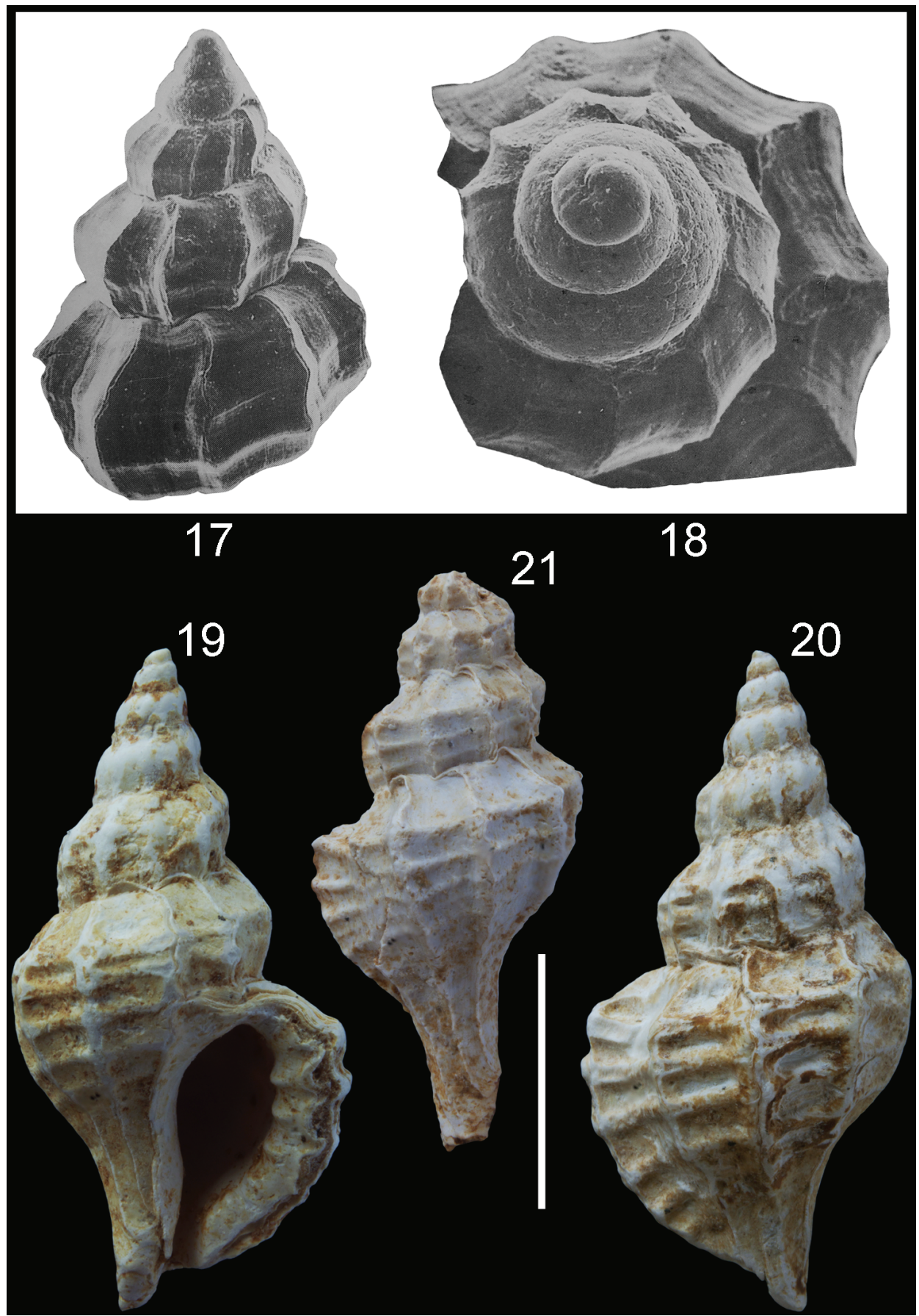

Figs 17-21. Paziella (Flexopteron) zsoldosi n. sp. - Figs 17-18. Csabdi, SL unknown. - Fig. 17. Lateral view. - Fig. 18. Apical view (refigured from KeCSKEMÉTi-KöRMENDY 1990, pl. 29, figs 5-6). - Figs 19-20. HNHM PAL 2020.20.1., holotype, Tés, SL 13. - Fig. 19. Apertural view. - Fig. 20. Abapertural view. - Fig. 21. Coll. Zsoldos, Tés, SL 11.4, abapertural view. Scale bar: $5 \mathrm{~mm}$ 
(Schlotheim, 1820), Tympanotonos aculeatus (Schlotheim, 1820), Cerithium subcorvinum Oppenheim, 1894, Editharus roncanus (Brongniart, 1823), Ampullina perusta (Defrance in Brongniart, 1823), Deshayesia alpina (d'Orbigny, 1850), Stilospirula doroghensis (Oppenheim, 1892), Tectonatica pasinii (Bayan, 1870), Globularia incompleta (Zittel, 1862), Clavilithes noae Lamarck 1803, Dilatilabrum fortisi (Brongniart, 1823), Timbellusmicropterus (Deshayes), ?Pterocheluscontabulatus gantensis (Szőts), Paziella (Flexopteron) sp., Janiopsis n. sp. and Hemiconus eszterhazyi (Papp, 1897).

\section{Paziella (Flexopteron) sp.}

(Figs 22-24)

\section{Material - HNHM INV 2020.25., INV 2020.26. (2).}

Remarks - The juvenile specimens from the Late Lutetian mollusc assemblage of Tés possess multispiral protoconch, sculpture of seven varices on the last whorl, and slightly spiny $\mathrm{P} 1$. These features are typical of $P$. (Flexopteron). However, early whorls of different Eocene species of the subgenus are very similar (see above), and the species level identification seems impossible in lack of adult morphology. Nevertheless, the specimens indicate diverse occurrence of the subgenus in the Middle Eocene HPB.

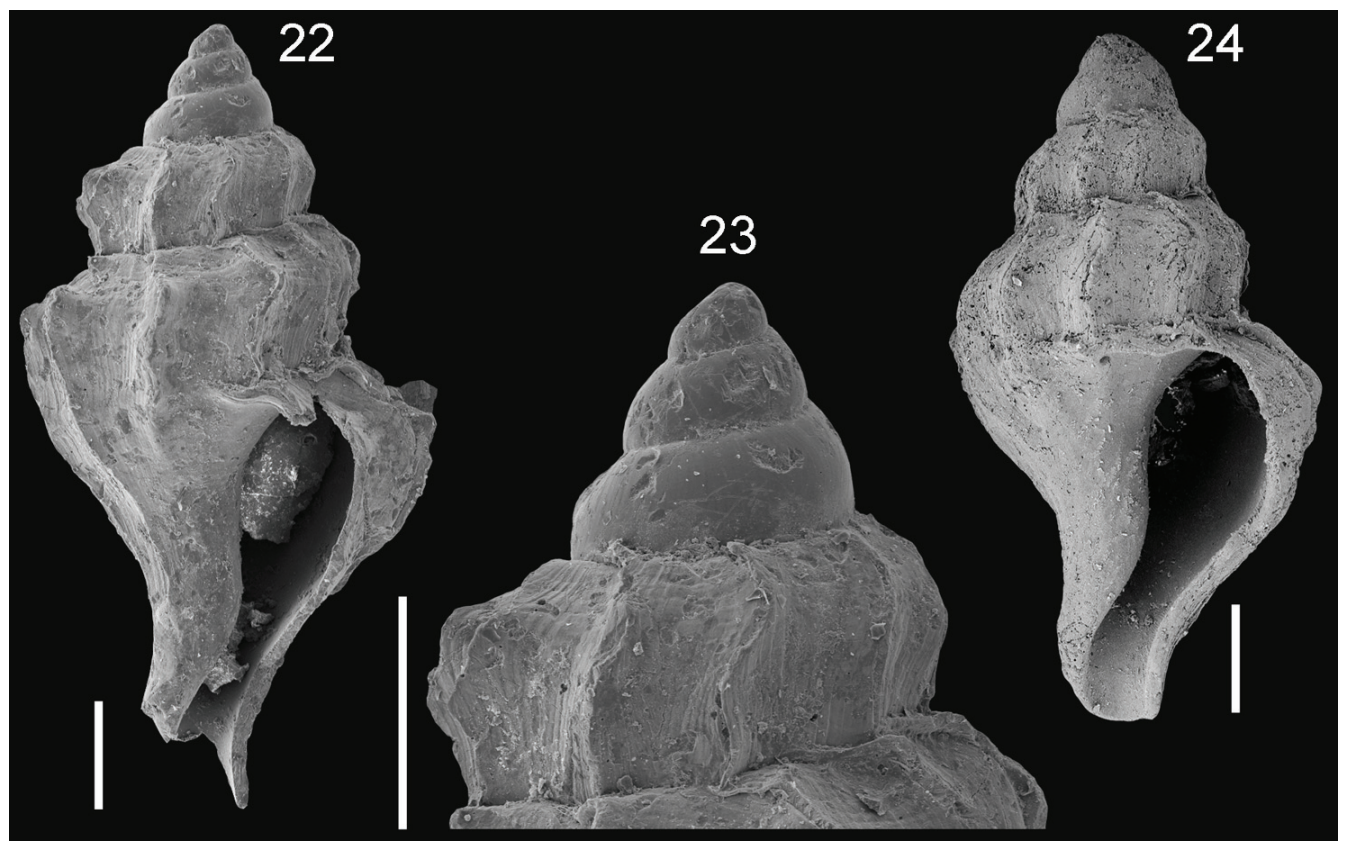

Figs 22-24. Paziella (Flexopteron) sp. - Figs 22-23. HNHM INV 2020.25., Tés, SL 3.6, apertural views. - Fig. 24. HNHM INV 2020.26., Tés, SL 3.2, apertural view (Photos: A. Dulai). Scale bar: $500 \mu \mathrm{m}$ 
Genus Harmatia Noszky, 1940

Type species: Murex (Harmatia) stephani Noszky, 1940

Harmatia tokodensis n. sp.

(Fig. 25)

2020 Harmatia sp. - DulaI, p. 202, fig. G.

Holotype - HNHM M.62.7135, SL 72 (P1 spine not included) (Collected by Endre Szőts in 1956).

Type strata and locality - Upper Lutetian-Lower Bartonian grey marl, Tokod, Hungary.

Derivation of name - The name refers to the type locality.

Material - Holotype.

Diagnosis - Trivaricate Harmatia species with rounded teleoconch whorls, ovate aperture, long siphonal canal, narrow primary spiral cords, and long primary cord spines.

Description - Medium-sized shell, protoconch missing, subfusiform teleoconch. Spire of three shouldered, rounded whorls. Last whorl $89 \%$ of the total length of the preserved shell (without P1 spine). Aperture ovate, internal part not seen. Siphonal canal without cord spines, long, narrow and slightly curved, penultimate siphonal canal present. Spiral sculpture of moderately developed, narrow primary cords (P1-P4 visible on last whorl), axial sculpture of three spiny varices per whorl without intervarical ribs. Well-developed, long and open P1-P6 spines on last whorl, P1 spine slightly adapically curved, no intervarical ribs.

Remarks - The morphology of the new species corresponds to the diagnosis of genus Harmatia (see MERLE et al. 2011). The genus has been known from the Early Oligocene in Hungary and Austria with two species; the Middle Eocene occurrence of $H$. tokodensis $\mathrm{n}$. sp. extends the stratigraphic range. Both $H$. stephani (Noszky 1940, pl. 2, fig. 4; refigured by MERLE et al. 2011, text-fig. 63/1), and $H$. guembeli longispina (NoszKY 1940, pl. 1, fig. 31; refigured by MERLE et al. 2011, text-fig. 63/2) (Kiscellian, Budapest Újlak) are distinguishable by much lower spire, and $H$. stephani bears almost straight siphonal canal. The spire and sculpture of $H$. guembeli guembeli (Dreger) (Kiscellian, Bad Häring, Budapest Ujlak) resemble that of $H$. tokodensis n. sp., the former, however, differs by strongly curved long siphonal canal. This feature cannot be seen on the fragmentary type specimen (DREGER 1892, pl. 4, fig. 5; refigured by LÖFFLER 1999, pl. 12, fig. 1, and MERLE et al. 2011, text-fig. 63/3), but clearly visible on other specimens illustrated by LÖFFLER (1999, pl. 12, figs 2-5). 


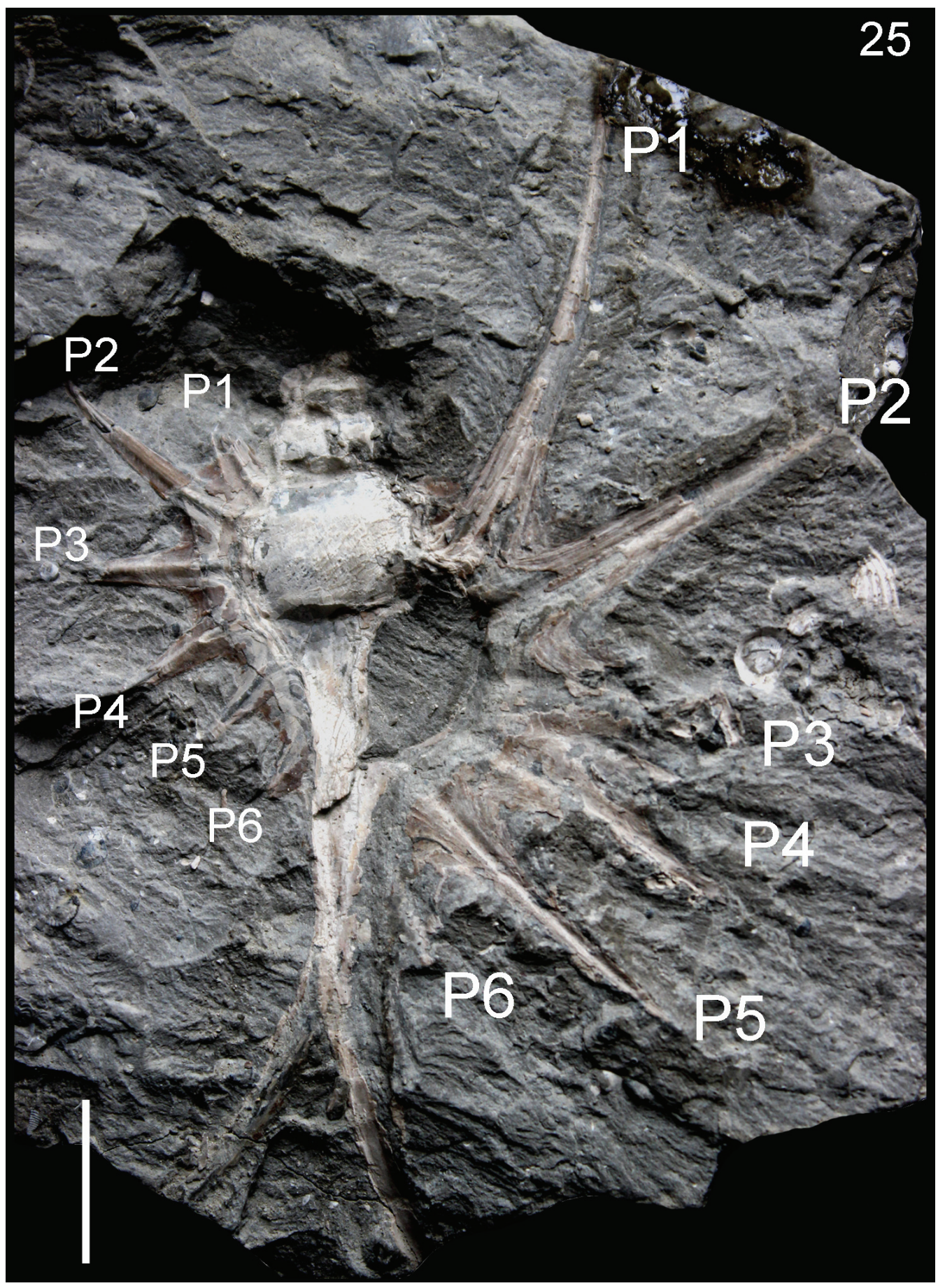

Fig. 25. Harmatia tokodensis n. sp., HNHM M.62.7135., holotype, Tokod, SL 72, apertural view (Photo: M. Szabó). Scale bar: $10 \mathrm{~mm}$ 
Genus Ponderia Houart, 1986

Type species: Typhis zealandicus (Hutton, 1873)

Ponderia bispinosa (J. de C. Sowerby, 1823)

(Figs 26-27)

1823 Murex bispinosus - J. DE C. Sowerby, p. 15, pl. 416, fig. 2.

1865 Murex Caillati - Deshayes, p. 316, pl. 87, figs 24-26.

1910-1913 Murex (Alipurpura) bispinosus (Sowerby) - Cossmann \& Pissarro, pl. 35, fig. $169 / 6$.

2011 Ponderia bispinosa (J. de C. Sowerby) - Merle et al., textfig. 52/D-E, p. 484, pl. 120, figs 4-7, pl. 121, figs 1-5.

Material - IFSM: 62756 (1).

Remarks - A fragmentary specimen is illustrated on the website of the International Fossil Shell Museum as Ponderia caillati (www.fossilshells.nl/ hungeo 40.html; download: 02.10.2019), it was collected by Rudi Hessel on the mine dump of the old brown coal mine of Dudar. The size (SL 31) and the general morphology agree well with that of the P. bispinosa material presented by Merle et al. (2001). Murex caillati Deshayes is a junior synonym of M. bispinosus J. de C. Sowerby.

Distribution - Lutetian-Priabonian, NE Atlantic: Paris Basin (France), Hampshire Basin (England), North Sea Basin (Germany), Alpine Tethys: Hungarian Paleogene Basin: Dudar.

Genus Typhina Jousseaume, 1880

Type species: Typhis belcheri Broderip, 1833

Typhina sp.

(Fig. 29)

Material - HNHM: M.62.1218.

Remarks - Two fragmentary specimens in the gastropod assemblage of Dudar belong to the subfamily Typhinae. The very poor preservation of the specimen on Figure 28 does not allow generic assignment, the other one represents genus Typhina (Fig. 29). The poor preservation, however, prevents the species level determination, as the investigation of the protoconch is necessary to the identification of typhinine species (MERLE \& PACAUD 2019). The genus is widespread in the Eocene NE Atlantic province; it is recorded for the first time in the HPB. 


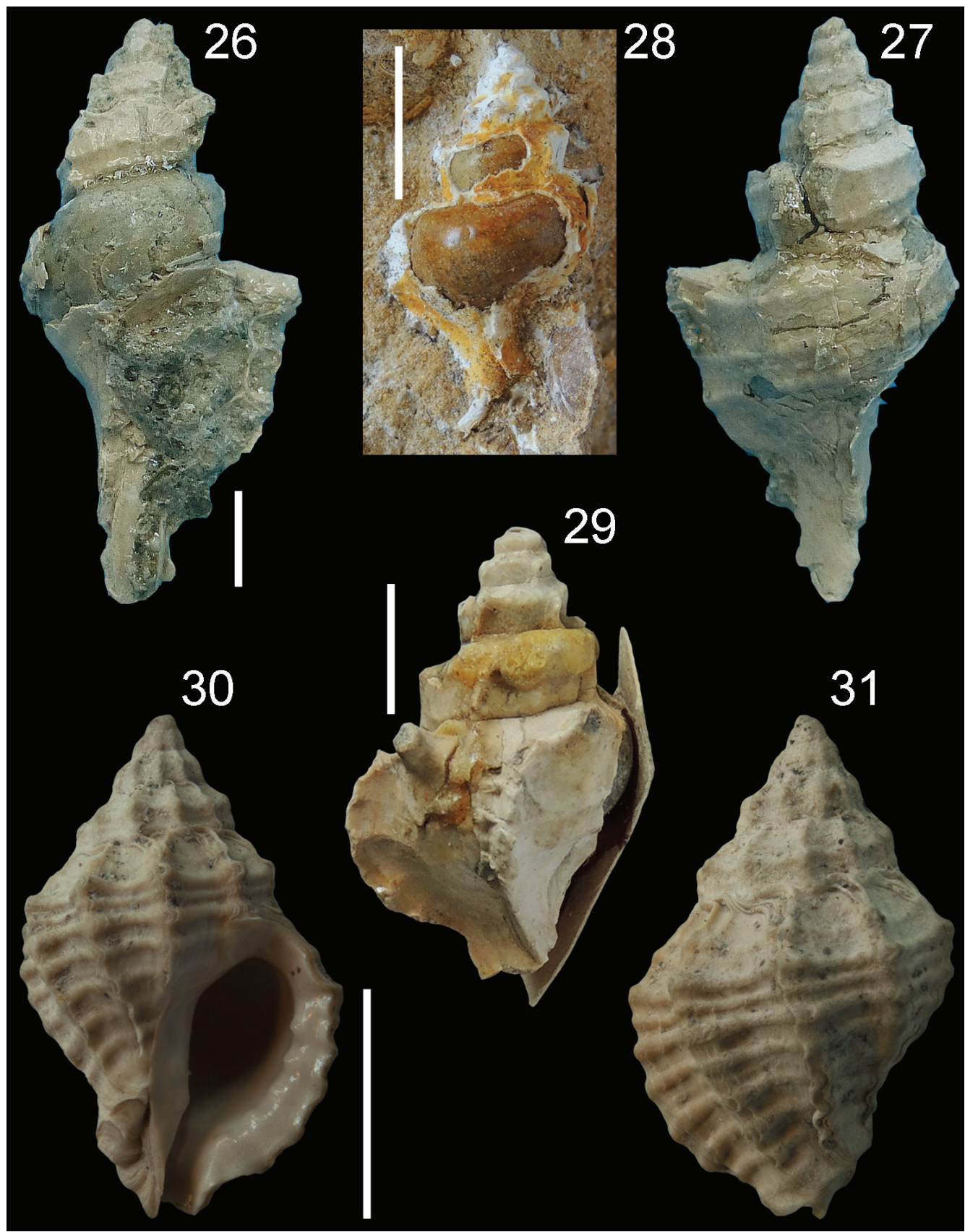

Figs 26-27. Ponderia bispinosa (Sowerby), IFSM INV 62756, Dudar, SL 31. Fig. 26. Apertural view. - Fig. 27. Abapertural view (Photo: R. Hessel). - Fig. 28. Typhinae sp. indet., Coll. Vicián, Dudar, SL 12, abapertural view. - Fig. 29. Typhina sp., HNHM M.62.1218., Dudar, SL 18, abapertural view. - Figs 30-31. Nucellopsis dudariensis (Strausz), MGSH E.467, holotype of Cantharus (Pollia) dudariensis Strausz, Dudar, SL 11. - Fig. 30. Apertural view. - Fig. 31. Abapertural view.

Scale bar: $5 \mathrm{~mm}$ 
Genus Nucellopsis Merle, 2005

Type species: Murex plicatilis Deshayes, 1835

Nucellopsis dudariensis (Strausz, 1966)

(Figs 30-31)

v 1966 Cantharus (Pollia) dudariensis n. sp. - STrausz, p. 130, pl. 15, figs 6-7.

2005 b Nucellopsis dudariensis (Strausz) nov. comb. - MERLE, 183.

Material-MGSH: E.467 (Holotype).

Remarks - Cantharus (Pollia) dudariensis Strausz was revised and reinterpreted as a representative of genus Nucellopsis by MERLE (2005b). The genus is typical of coastal or lagoon environments. $N$. dudariensis is an endemic species in the HPB and very rare, only the holotype is known from the type locality, Dudar. The Bartonian specimens in the Paris Basin described by MerLe $(2005 b)$ as $N$. dudariensis differ in morphology; they probably represent a new Nucellopsis species (D. Merle's personal communication). Concerning another appearance of Nucellopsis in the Alpine Tethys, a specimen was recorded by Lorenc (1950: 308, pl. 5, fig. 13) as Muricopsis plicatilis (Deshayes) from the Lutetian-Bartonian of the Vyškov Depression (Czechia). However, the fragmentary specimen differs from $N$. plicatilis by more slender shell, its determination needs to be revised.

Distribution - Late Lutetian, Alpine Tethys: Hungarian Paleogene Basin: Dudar.

\section{CONCLUSIONS}

Based on new field works and revisions of museum collections eight muricid species and genus Typhina are described in this paper from the Middle Eocene Hungarian Paleogene Basin system. The most abundant and widely distributed species is ?Pterochelus contabulatus gantensis (Szöts), it occurs from the Bakony to the Gerecse Mts with more than 100 specimens. Among the fossiliferous sites of the HPB Dudar (Bakony Mts) is characterized by the highest muricid diversity, six species and genus Typhina appear in the gastropod assemblage. Paziella (Flexopteron) zsoldosi n. sp. extends the palaeogeographic distribution, while Harmatia tokodensis $\mathrm{n}$. sp. extends the stratigraphic range of these genera. The relatively low alpha diversity of the Muricidae in the HPB is typical of the Alpine Tethys (see Boussac 1911; Dainelli 1915, 1919; De Gregorio 1880, 1895; Fabiani 1908, 1915; Oppenheim 1894; Vinassa de Regny 1896, 1897).

Concerning the faunal composition, from the assemblage presented herein three species (Timbellus barattus, T. micropterus, Ponderia bispinosa) and 
genus Typhina are known in the NE Atlantic, two species (Timbellus barattus, T. micropterus) were recorded from $\mathrm{W}$ Alpine Tethys localities, and one species (Timbellus priabonicus) occurs in the North Sea Basin and the Ukrainian Archipelago. ?Pterochelus contabulatus gantensis, Paziella (Flexopteron) zsoldosi n. sp., Harmatia tokodensis n. sp., and Nucellopsis dudariensis seem to be endemic species in the Hungarian Paleogene Basin.

Acknowledgements - We thank Alfréd Dulai (HNHM), Attila Ösi (Eötvös University, Budapest), Csilla Galambos, László Makádi and Bálint Péterdi (MGSH), Jean-Michel Pacaud (France), Ortwin Schultz (Austria), Sonja Löffler (Germany), A. A. Berezovsky (Ukraine), and Mikhail Rogov (Russia) for their professional help. Special thanks to Didier Merle (Muséum National d'Histoire Naturelle, Paris) whose critical comments helped significantly to improve the manuscript. Fossil collectors (Tibor Berta, Zoltán Evanics, István Gurdon, Rudi Hessel, and Márton Zsoldos) kindly offered their materials for study. Figure 1 was produced by Domonkos Verestói-Kovács.

\section{REFERENCES}

BÁLDI-BEKE M. \& BÁLDI T. 1990: Subsidence history of the Bakony Eocene basin in W-Hungary. - Általános Földtani Szemle 25: 83-118. (in Hungarian with English abstract)

Bitner M. A., Dulai A. \& Galácz A. 2011: Middle Eocene brachiopods from the Szőc Limestone Formation (Bakony Mountains, Hungary), with a description of a new genus. - Neues Jahrbuch für Geologie und Paläontologie, Abhandlungen 259: 113-128.

https://doi.org/10.1127/0077-7749/2010/0113

Boussac J. 1911: Études paléontologiques sur le Nummulitique alpin. - Mémoire de la Carte géologique de France 1: $437 \mathrm{pp}$.

BudAI T. (ed.) 2018: Geology of the Gerecse Mountains. Regional map series of Hungary. - Mining and Geological Survey of Hungary, Budapest, $490 \mathrm{pp}$.

BUdAI T. \& Fodor L. (eds) 2008: Geology of the Vértes Hills. Regional map series of Hungary. - Geological Institute of Hungary, Budapest, $368 \mathrm{pp}$.

Cossmann M. \& Pissarro G. 1910-1913: Iconographie complète des Coquilles fossiles de l'Éocène des Environs de Paris. Tome 2. - Paris, 65 pls.

DAINELli G. 1915: L'eocene friuliano. - Ricci, Firenze, 721 pp.

Dainelli G. 1919: Fossili eocenici della Croazia costiera. - Atti della Società Toscana di Scienze Naturali, Memorie 32: 3-57.

De Gregorio A. 1880: Fauna di San Giovanni Ilarione (Parisiano). Part I (Cefalopodi e Gasteropodi). - Montaina, Palermo, 106 pp.

De Gregorio A. 1895: Description des faunes tertiaires de la Venetie, fossiles de Lavacille, près de Bassano. - Annales de Géologie et de Paléontologie 20: 1-24.

Dell'Angelo B., Sosso M., Kroh A. \& Dulai A. 2015: Polyplacophora from the Eocene of Gánt, Hungary. - Bulletin of Geosciences 90(2): 359-370.

https://doi.org/10.3140/bull.geosci.1517

Deshayes J.-P. 1835: Description des Coquilles fossiles des environs de Paris. - Deshayes, Paris, 814 pp.

Deshayes J.-P. 1864-1865: Description des animaux sans vertèbres découverts dans le bassin de Paris, 3. - Baillière et Fils, Paris, 667 pp. 
Dreger J. 1892: Die Gastropoden von Häring bei Kirchbichl in Tirol. - Annalen des K.K. Naturhistorischen Hofmuseums 7: 11-34.

Dulai A. (ed.) 2020: Eocén élövilág a Kárpát-medencében. Üvegház-22 millió éven át. [Eocene wildlife in the Carpathian Basin. 22 million years-long greenhouse period.] - Természettár Könyvsorozat, Magyar Természettudományi Múzeum, Budapest, 328 pp. (in Hungarian)

Fabiani R. 1908: Paleontologia dei Colli Berici. - Memorie della Società Italiana delle Scienze 3(15): 45-249.

Fabiani R. 1915: Il Paleogene del Veneto. - Memorie dell'Istituto Geologico della R. Università di Padova 3: 1-336.

Glibert M. 1933: Monographie de la faune malacologique de Bruxellien des environs de Bruxelles. - Mémoires du Musée Royal d'Histoire Naturelle de Belgique 54: 216 pp.

HAAS J. (ed.) 2012: Geology of Hungary. - Springer Verlag, Berlin, Heidelberg, 244 pp.

Karagivleva J. D. 1964: Les fossiles de Bulgarie VI a, Paléogène Mollusca. - Académie des Scientes de Bulgarie, Sofia, 270 pp.

KecskemÉTi-Körmendy A. 1972: Die Eozäne Molluskenfauna des Doroger Beckens. - Jahrbuch der Ungarischen Geologischen Anstalt 55(2): 143-377.

KeCSKEMÉTi-KöRMENDY A. 1980: Le faune des Mollusques du faciès de bassin éocène du Bakony nord-oriental. - Jahrbuch der Ungarischen Geologischen Anstalt 63(3): 1-227.

KeCSKEMÉTi-Körmendy A. 1990: La faune de mollusques éocènes du bassin Nagyegyháza Csordakút - Mány. - Jahrbuch der Ungarischen Geologischen Anstalt 71(1): 1-269.

KerCSMÁr Zs. (ed.) 2015: Surface geology of Hungary. - Geological and Geophysical Institute of Hungary, Budapest, 66 pp.

KLUSHNikov M. N. 1958: Stratigraphy and fauna of the Lower Tertiary deposits of Ukraine. Transactions of the Geological Institute, Academy of Sciences of the Ukrainian SSR, Ser. Stratigraphy and Paleontology 13: 1-549.

Koenen A. von 1889: Das Norddeutsche Unter-Oligocän und seine Mollusken-Fauna 1: Strombidae, Muricidae, Buccinidae. - Abhandlungen zur geologischen Specialkarte von Preussen und den Thüringischen Staaten 10(1): 1-280.

KRACH W. 1985: The Eocene mollusc fauna from Koniusza near Przemyśl (Polish Eastern Carpathians). - Annales Societatis Geologorum Poloniae 55(1-2): 139-190.

Kuźniar W. 1910: Das Eozän der Tatra und des Podhale, I. - Comptes rendus de la Commission de Physiographie 44: IV.26-76. (in Polish)

Less Gy., Báldi-Beke M., Kecskeméti T., Kollányi K., Kertész B. \& Varga I. 2000: Western part of the Dorog Basin. In: BAssi D. (ed.): Field trip guide book. Shallow water benthic communities at the Middle-Upper Eocene boundary. Southern and North-Eastern Italy, Slovenia, Croatia, Hungary. - Annali dell'Università di Ferrara, Scienze della terra 5(8), Supplement: 161-168.

LoRENC L. 1950: The Eocene fauna from Heršpice near Slavkov. - "Sborník" du Service géologique de la République Tchécoslovaque 17: 269-351. (in Czech with English summary)

LöFFLER S.-B. 1999: Systematische Neubearbeitung und paläoökologische Aspekte der unteroligozänen Molluskenfauna aus den Zementmergeln von Bad Häring (Unterinntal, Tirol). Tübinger Geowissenschaftliche Arbeiten A: Geologie, Paläontologie, Stratigraphie 54: 1-207.

Makarenko D. E. \& Zelinskaya V. A. 1982: Mollusks from the Middle Eocene of Platform Ukraine. - Dumka, Kiev, 167 pp.

MERLE D. 2001: The spiral cords and the internal denticles of the outer lip in the Muricidae: terminology and methodological comments. - Novapex 2(3): 69-91.

Merle D. 2005a: The spiral cords of the Muricidae (Gastropoda, Neogastropoda): importance of ontogenetic and topological correspondences for delineating structural homologies. Lethaia 38: 367-379. 
Merle D. 2005b: Nucellopsis (Gastropoda, Muricidae), a new genus from the paralic domain of the European Palaeogene. - Comptes Rendus Palevol 4: 177-189.

https://doi.org/10.1016/j.crpv.2004.11.005

Merle D. \& Pacaud J.-M. 2019: Five new muricid species (Mollusca, Gastropoda) from the Eocene of France, Senegal and Pakistan. - Xenophora Taxonomy 25: 11-22.

Merle D., Garrigues B. \& Pointier J.-P. 2011: Fossil and Recent Muricidae of the World. Part Muricinae. - ConchBooks, 648 pp.

Mihály S. \& VinCZe P. 1984: New paleoecological remarks concerning the Middle Eocene beds of the Bagoly-hegy at Gánt, Transdanubia, Hungary. - Földtani Közlöny 114(3): 263-283. (in Hungarian with English abstract)

MikUž V., Čvorović B. \& BARTOL M. 2013: Selected molluscs from the Eocene flysch of Goriška brda, western Slovenia. - Folia Biologica et Geologica 54(1): 47-94.

Moisescu V., MÉszáros N. \& CHIra C. 1991: Contributions to the revision of the Eocene molluscan fauna from the Cluj - Huedin area (north western Transylvania) and to its local biostratigraphical distribution. - Studia Universitatis Babeş-Bolyai, Ser. Geologia 36(2): 71-83.

Noszky J. 1940: Die Molluskenfauna des Kisceller Tones (Rupelien) aus der Umgebung von Budapest. II. Teil: Loricata, Gastropoda, Scaphopoda. - Annales Musei nationalis hungarici 33: $1-80$.

Oppenheim P. 1894: Die eocäne Fauna des Mt. Pulli bei Valdagno im Vicentino. - Zeitschrift der Deutschen geologischen Gesellschaft 46(2): 309-445.

Oppenheim P. 1901: Die Priabonaschichten und ihre Fauna, im Zusammenhange mit gleichalterigen und analogen Ablagerungen. - Palaeontographica 47: 1-348.

Oppenheim P. 1922: Über Alter und Fauna des Tertiärhorizontes der Niemtschitzer Schichten in Mäbren. - Selbstverlage des Verfassers, Berlin, 106 pp.

Ozsvánt P. 1999: Middle Eocene foraminifer, mollusc and ostracod fauna from the Csordakút Basin (Gerecse Mountains, Hungary): palaeoenvironments recorded in a transgressive sequence. - Annales Universitatis Scientiarum Budapestinensis de Rolando Eötvös nominatae, Sectio Geologica 32: 73-135.

Ozsvá RT P. 2007: Dudar. - In: PÁlfy J. \& Pazonyi P. (eds): Paleontological excursions in Hungary and Transsylvania, Hantken Kiadó, Budapest, pp. 92-93. (in Hungarian)

PaCAud J.-M. 2018: Timbellus danapris nov. sp., une espèce nouvelle de Muricidae (Mollusca, Gastropoda) du Priabonien (Éocène supérieur) de Dnipro (Oblast de Dnipropetrovsk, Ukraine). - Novapex 19(4): 107-116.

Pacaud J.-M. \& Vicián Z. 2019: Description of a new species of Subepona Dolin et Lozouet, 2004 (Mollusca: Cypraeoidea) from the Lutetian (Middle Eocene) of Hungary. - Fragmenta Palaeontologica Hungarica 35 (2018): 103-110.

https://doi.org/10.17111/FragmPalHung.2018.35.103

PAPŠOvÁ J. 1972: Sur les représentants de la super-famille des Cerithiacea de l'Eocène de la Slovaquie. - Zborník Geologických Vied Západné Karpaty 16: 149-203.

Sowerby J. DE C. 1823: The Mineral Conchology of Great Britain. Vol. 5. - Taylor, London, 168 pp.

STRAUSZ L. 1962: Über die paläoökologischen Verhältnisse der Eozänfauna von Gánt. - Földtani Közlöny 92(3): 308-318.

Strausz L. 1966: Die Eozängastropoden von Dudar in Ungarn. - Geologica Hungarica, series Palaeontologica 33: 1-199.

STrausz L. 1969: Über Kleinmollusken aus dem Mittel-Eozän von Dudar I. - Földtani Közlöny 99(2): 147-154.

STRAUSz L. 1970a: Über Kleinmollusken aus dem Eozän von Dudar II. - Földtani Közlöny 100(1): 66-76. 
Strausz L. 1970b: Über Kleinmollusken aus dem Mittel-Eozän von Dudar III. - Földtani Közlöny 100(4): 354-359.

Strausz L. 1974: Die Eozänmollusken von Neszmély (Ungarn). - Geologica Hungarica, series Palaeontologica 38: 1-160.

SzŐTs E. 1953: Mollusques Éocènes de la Hongrie I. Les mollusques éocènes des environs de Gánt. - Geologica Hungarica, series Palaeontologica 22: 1-241.

SzöTs E. 1956: L’Éocène (Paléogène) de la Hongrie. - Geologica Hungarica, series Geologica 9: 1-320.

Tracey S., Todd J. A., Le Renard J., King C. \& Goodchild M. 1996: Distribution of Mollusca in units $S 1$ to $S 9$ of the Selsey Formation (middle Lutetian), Selsey Peninsula, West Sussex. Tertiary Research 16(1-4): 97-139.

Vicián Z., KRock H. \& Kovács Z. 2017: New gastropod records from the Cenozoic of Hungary. - Földtani Közlöny 147(3): 265-282. https://doi.org/10.23928/foldt.kozl.2017.147.3.265

Vinassa De Regny P. E. 1896-1897: Synopsis dei molluschi terziari delle Alpi venete. Parte prima: Strati con Velates Schmiedeliana. I. Monte Postale. II. S. Giovanni Ilarione. III. Roncà. - Palaeontographia Italica, Memorie di Paleontologia 1(1895): 211-275, 2(1896): 149-184.

Zelinskaya V. A., Kulichenko V. G., Makarenko D. E. \& Sorochan E. A. 1968: Gastropod and scaphopod mollusks of the Paleogene and Miocene of Ukraine. - Paleontologiceskij Spravochnik 2: 1-282. (in Russian) 